\title{
Finance Education is imperative for enhancing Financial Capability of Indian citizens
}

\author{
Dr. Lokanath Mishra \\ ${ }^{I}$ Professor, Usha \& Lakshmi Mittal Institute of Management, Copernicus Lane, Kasturba Gandhi Marg, New \\ Delhi- 110001
}

\begin{abstract}
Financial Capability is defined as a combination of awareness, knowledge, skill, attitude and behaviour necessary to make sound financial decisions and ultimately achieve individual financial wellbeing. Finance education can develop required awareness and provide relevant financial knowledge. Financial training can render appropriate skills and competence. Social marketing can ensure attitudinal change and behavioural modification. Thus finance education is an important component of the developmental mechanism for enhancing financial capability. Finance education is a must for everyone. However, policy makers will have to address finance education needs of kids, school students, college / university students, youths, retirees / senior citizens, women, defence personnel, parents, teachers and employees separately in order to get the best results. Indian Government and regulatory bodies in the financial sector will have to do their bit to ensure that appropriate finance education is provided to all citizens and their financial capability is enhanced.
\end{abstract}

Key Words: Finance Education, Financial Literacy, Financial Capability, Financial Responsibility, Financial Wellbeing, Financial Planning.

\section{Introduction:}

The OECD has defined financial education as, 'The process by which financial consumers / investors improve their understanding of financial products and concepts and, through information, instruction and /or objective advice, develop the skills and confidence to become more aware of financial risks and opportunities, to make informed choices, to know where to go for help, and to take other effective actions to improve their financial well-being'.

Financial Capability (Literacy), on the other hand, is defined by OECD International Network on Financial Education (INFE), as a combination of awareness, knowledge, skill, attitude and behaviour necessary to make sound financial decisions and ultimately achieve individual financial wellbeing. Education develops awareness and provides knowledge. Training renders skills and competence. Social marketing ensures attitudinal change and behavioural modification. Thus finance education plays a key role for enhancing financial capability.

Financial capability (literacy) thus has three key components:

$\square$ Financial knowledge and understanding;

$\square$ Financial skills and competence; and

$\square$ Financial responsibility which leads to desired attitude / behaviour.

Determinants of Financial Capability:

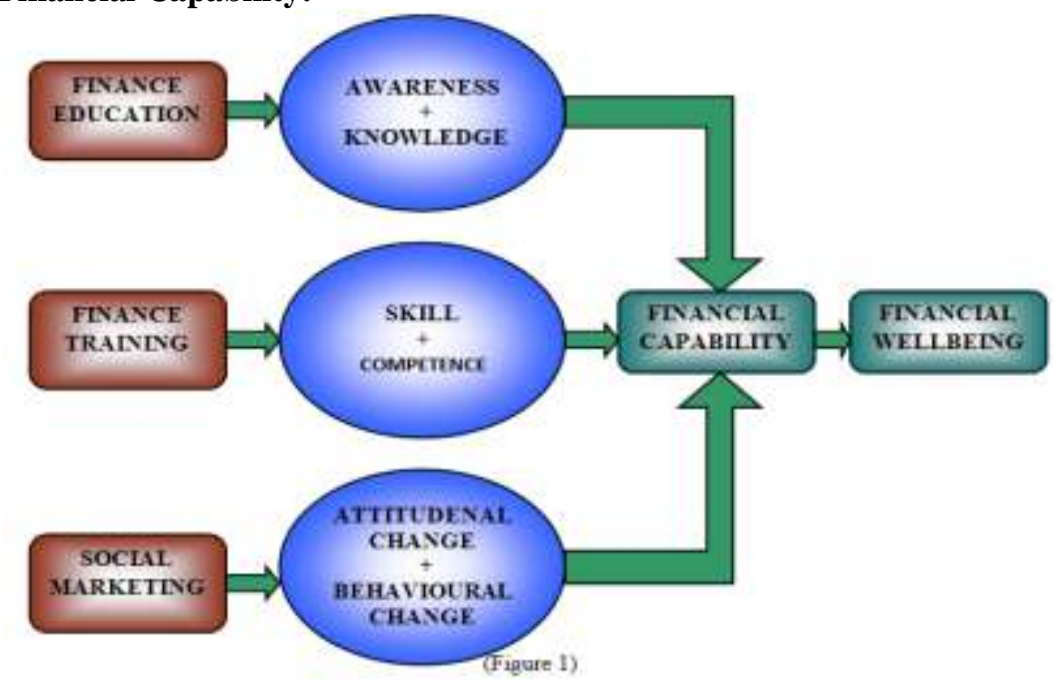


In a world of increasing (financial) risks, financial education and awareness issues and policies have become critically important for several reasons:

(a) Increasing transfer of risks to households which are more directly responsible for essential financial decisions for their future wellbeing.

- Increased life expectancy

- Life expectancy of women higher compared to that of men

- Replacement of joint family structure by nuclear family structure

- Enhanced individual responsibility in credit, health, pensions and insurance products

- More households investing more income in financial assets

(b) Uncertainties and sophistication of the financial landscape

- More complex products and increased supply of competing financial products

- Overload of financial disclosure

- Ever-changing financial regulations

- Integration of financial markets and market forces

(c ) Very low level of financial literacy and capability of individuals in all countries

- Individuals normally overestimate their financial knowledge and skills

- Lack of confidence of individuals in financial institutions and financial markets

- Markets getting affected by scams, manipulations and speculations of all kinds

- Vulnerable groups in the society are particularly affected in the process

Research studies suggest a direct causal link between financial education and positive outcomes. There is evidence that those with higher financial literacy better manage their money.

\section{How to improve financial literacy/ education? \\ Major OECD Recommendations}

India as a member country, need to follow and act on these recommendations

1. Governments and all concerned stakeholders should promote unbiased, fair financial education.

2. Programs should be coordinated and developed with efficiency.

3. The development of methodologies to assess existing financial education programs should be promoted.

4. Financial education should start at school, for people to be educated as early as possible.

5. Financial education should be part of the good governance of financial institutions, whose accountability and responsibility should be encouraged.

6. Financial education should be clearly distinguished from commercial advice; codes of conduct for the staff of financial institutions should be developed.

7. Financial institutions should be encouraged to check that clients read and understand information, especially when related to long-term commitments or financial services with potentially significant financial consequences: small print and abstruse documentation should be discouraged.

8. Financial education programs should focus particularly on important life-planning aspects, such as basic savings, debt, insurance or pensions.

9. Programs and delivery strategies should be oriented towards financial capacity building, where appropriate targeted on specific groups and made as personalized as possible.

10. Future retirees should be made aware of the need to assess the finance adequacy of their current public and private pension schemes.

11. National campaigns, specific Web sites, free information services and warning systems on high-risk issues for financial consumers (such as fraud) should be promoted

\section{Financial Planning Education Survey}

The author (Mishra) conducted a Financial Planning Education Survey in 2011 as a part of his doctoral research. For the purpose of this research study, a questionnaire was designed and sent to about 150 educationists, education providers, corporate bodies, NGOs dedicated to providing education to vulnerable groups of the society, out of which 47 (about 30\%) responded.

\section{Profile of Respondents}

\begin{tabular}{|l|l|}
\hline Type of Respondents & Number of Respondents \\
\hline Educationist / Academician & 34 \\
\hline FPSB Approved Education Providers & 6 \\
\hline Educational Institution & 3 \\
\hline Corporate Body & 1 \\
\hline NGO & 1 \\
\hline Others & 2 \\
\hline Total & 47 \\
\hline
\end{tabular}

(Table 1) 


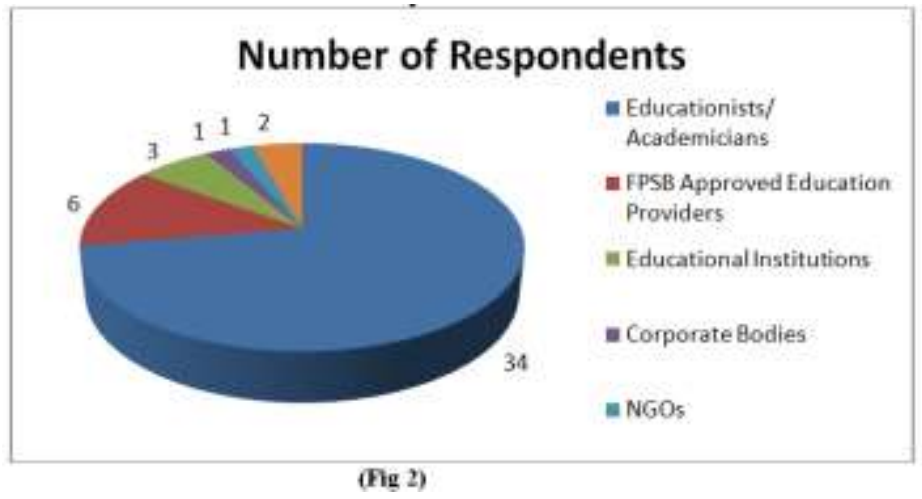

The distribution of experience profile of respondents has been provided below:

Experience Profile of Respondents

\begin{tabular}{|l|l|}
\hline $\begin{array}{l}\text { Number of Years of Experience in the field of } \\
\text { Education }\end{array}$ & Number of Respondents \\
\hline $1-5$ years & 18 \\
\hline $6-10$ years & 12 \\
\hline $11-15$ years & 5 \\
\hline $16-20$ years & 7 \\
\hline Above 20 years & 5 \\
\hline Total & 47 \\
\hline
\end{tabular}

(Table 2)

Experience Profile of Respondents

\section{Experience Profile of Respondents}

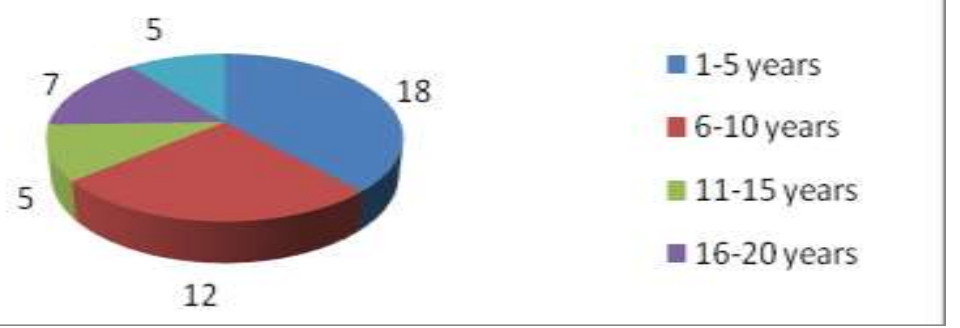

(figure 3)

(Location Profile of Respondents)

\begin{tabular}{|l|l|}
\hline Current Location & Number of Respondents \\
\hline Andhra Pradesh & 20 \\
\hline Ahmadabad & 1 \\
\hline Mumbai & 1 \\
\hline Bhubaneswar & 2 \\
\hline Chennai & 2 \\
\hline Bangalore & 3 \\
\hline Chandigarh & 1 \\
\hline Indore & 1 \\
\hline Nagpur & 1 \\
\hline Manipal & 1 \\
\hline Rajasthan & 3 \\
\hline Bhopal & 1 \\
\hline Noida (UP) & 1 \\
\hline Pune & 1 \\
\hline Delhi & 1 \\
\hline Ernakulam & 4 \\
\hline Kolkata & 3 \\
\hline Total & 47 \\
\hline
\end{tabular}

(Table 3) 


\section{Designing of the Questionnaire:}

Finance education is a must for everyone and as such, a questionnaire for this survey was designed to address the needs of all the social groups, viz., (i) Kids (ii) School Students (iii) College \& University Students / Youths (iv) Senior Citizens / Retired Persons (v) Women (vi) Military Personnel (vii) Parents (viii) Teachers and (ix) Employees. The questionnaire consisted of 20 questions for which responses were sought. The responses received were then coded for the purposes of analysis / interpretation.

\section{Response Analysis of \\ Financial Planning Education Questionnaire \\ (In Percentage Terms)}

\begin{tabular}{|c|c|c|c|c|}
\hline Question & $\begin{array}{c}\% \text { Agreed } \\
(\text { code }=+1)\end{array}$ & $\begin{array}{r}\% \text { Disagreed } \\
(\text { code }=-1)\end{array}$ & $\begin{array}{c}\text { \% said don't } \\
\text { Know } \\
(\text { code=0) }\end{array}$ & $\begin{array}{c}\text { Total Coded } \\
\text { Score }\end{array}$ \\
\hline $\begin{array}{l}\text { Q1. Imparting real life financial skills to } \\
\text { school students is critical to their holistic } \\
\text { development. Establishing sound financial } \\
\text { habits at a young age will prepare them for } \\
\text { financial success in future. }\end{array}$ & 92 & 4 & 4 & 88 \\
\hline $\begin{array}{l}\text { Q2. In this context, the "Pocket Money" } \\
\text { programme run by SEBI and NISM to } \\
\text { increase financial literacy among school } \\
\text { students is a success. But it is operating at } \\
\text { present on a pilot scale. It has to be } \\
\text { extended to majority of schools in India. }\end{array}$ & 83 & 9 & 8 & 74 \\
\hline $\begin{array}{l}\text { Q3.If children are not equipped with the } \\
\text { right skills, they will have a miserable } \\
\text { time, learning financial lessons the hard } \\
\text { way and making some horrendous } \\
\text { mistakes. }\end{array}$ & 81 & 11 & 8 & 70 \\
\hline $\begin{array}{l}\text { Q4 It is worthwhile to provide relevant } \\
\text { financial education to school students free } \\
\text { of cost through school, print media and } \\
\text { electronic media, conduct a certification } \\
\text { test at national level and provide } \\
\text { appropriate incentives for clearing the test. }\end{array}$ & 74 & 21 & 5 & 53 \\
\hline $\begin{array}{l}\text { Q5. Personal finance should be } \\
\text { compulsorily taught to college / university } \\
\text { students. Those who are majoring in } \\
\text { finance must study personal finance before } \\
\text { they study corporate finance. }\end{array}$ & 88 & 6 & 6 & 82 \\
\hline $\begin{array}{l}\text { Q6. Colleges / Universities may consider } \\
\text { running regular financial counselling } \\
\text { clinics with the help of reputed financial } \\
\text { advisors to advise students on financial } \\
\text { matters, especially on borrowings, } \\
\text { spending on credit cards, saving and } \\
\text { investing opportunities. }\end{array}$ & 85 & 11 & 4 & 74 \\
\hline $\begin{array}{l}\text { Q7. National Endowment on Financial } \\
\text { Education (NEFE), USA provides financial } \\
\text { resources for colleges, in the form of a } \\
\text { "Cash Course" on line, free of cost, which } \\
\text { aims at building money management skills, } \\
\text { surviving in a tough economy and } \\
\text { preparing for success. In India we may } \\
\text { consider to offer similar opportunities to } \\
\text { our college / university students. }\end{array}$ & 83 & 9 & 8 & 74 \\
\hline $\begin{array}{l}\text { Q8. Women face tremendous challenges as } \\
\text { they move through life's transitions, from } \\
\text { childhood to adult, from college to career, } \\
\text { from single to married, to widowhood or } \\
\text { divorce, and into the retirement years. And } \\
\text { women are concerned about the financial } \\
\text { well-being of their families as well as } \\
\text { themselves, making sure that those they }\end{array}$ & 94 & $\mathbf{0}$ & 6 & 94 \\
\hline
\end{tabular}




\begin{tabular}{|c|c|c|c|c|}
\hline $\begin{array}{l}\text { love are sheltered within their own } \\
\text { financial success. So women should be } \\
\text { financially empowered for their success in } \\
\text { life. }\end{array}$ & & & & \\
\hline $\begin{array}{l}\text { Q9. Women Institute of Financial } \\
\text { Education (WIFE) website provides } \\
\text { valuable financial educational resources for } \\
\text { women. Similar websites may be promoted } \\
\text { in India especially for women. Regional } \\
\text { TV channels, magazines in English } \\
\text { (Femina, Women's Era, and Society), } \\
\text { Hindi (Grihashobha) and other regional } \\
\text { languages, specially meant for Indian } \\
\text { women should devote a portion of their } \\
\text { coverage to financial education of women } \\
\text { in India. }\end{array}$ & 87 & $\mathbf{0}$ & 13 & 87 \\
\hline $\begin{array}{l}\text { Q10. Women play multiple roles as } \\
\text { mother, wife, sister, daughter, daughter-in- } \\
\text { law etc, during their life time in the family. } \\
\text { It would be prudent to involve women in } \\
\text { the financial decision making process in } \\
\text { the family. Once they understand finance } \\
\text { and get used to taking financial decisions, } \\
\text { they can easily teach, if not anyone else, } \\
\text { their own children. }\end{array}$ & 94 & 2 & 4 & 92 \\
\hline $\begin{array}{l}\text { Q11.Teachers should endeavour to } \\
\text { improve financial capability among young } \\
\text { students by using financial tools, resources } \\
\text { and activities to make the classroom fun } \\
\text { and engaging. Providing appropriate } \\
\text { training to teachers engaged in delivering } \\
\text { financial education to students may help } \\
\text { achieving this goal. }\end{array}$ & 94 & 2 & 4 & 92 \\
\hline $\begin{array}{l}\text { Q12. A child starts learning invaluable } \\
\text { lessons, from the time he takes birth, from } \\
\text { his parents. Parents, therefore, must learn } \\
\text { the basics of saving, investing, and } \\
\text { financial planning for themselves and their } \\
\text { loved ones' future. Parents should discuss } \\
\text { finance and their finance related decisions } \\
\text { with their children so as to make them } \\
\text { financially savvy. }\end{array}$ & 85 & 9 & 6 & 76 \\
\hline $\begin{array}{l}\text { Q13. Defence personnel face unique } \\
\text { financial challenges. They must learn how } \\
\text { to navigate their financial futures post } \\
\text { retirement from defence services. Many of } \\
\text { them also take retirement at middle age, } \\
\text { after completion of a minimum required } \\
\text { number of years in service. Finance } \\
\text { education for defence personnel is } \\
\text { therefore extremely important and may be } \\
\text { provided while they are in service and } \\
\text { subsequently by the rehabilitation wing to } \\
\text { the retirees. }\end{array}$ & 96 & 2 & 2 & 94 \\
\hline $\begin{array}{l}\text { Q14. Retirees must be given adequate } \\
\text { financial education as regards to the steps } \\
\text { they and their families can take to achieve } \\
\text { financial security and financial } \\
\text { independence in life in the post retirement } \\
\text { period. }\end{array}$ & 96 & 0 & 4 & 96 \\
\hline $\begin{array}{l}\text { Q15. NGOs, Developmental Agencies and } \\
\text { Insurance Companies who offer retirement } \\
\text { planning advice may take the lead to } \\
\text { address the personal finance education } \\
\text { needs of retirees and senior citizens. Young } \\
\text { and educated children of the retirees and }\end{array}$ & 89 & 3 & 8 & 86 \\
\hline
\end{tabular}




\begin{tabular}{|c|c|c|c|c|}
\hline $\begin{array}{l}\text { senior citizens may also help educating } \\
\text { their old parents on finance matters. }\end{array}$ & & & & \\
\hline $\begin{array}{l}\text { Q16. Employers who offer personal } \\
\text { finance education to employees under their } \\
\text { employee benefit scheme convey that they } \\
\text { are concerned with their long term welfare. } \\
\text { However, employers typically offer only } \\
\text { narrowly focused financial education about } \\
\text { retirement. They should offer } \\
\text { comprehensive personal finance employee } \\
\text { education, because the cost is low and } \\
\text { benefits are high. }\end{array}$ & 90 & 2 & 8 & 88 \\
\hline $\begin{array}{l}\text { Q17. Financial education within the } \\
\text { workplace has become a necessity because } \\
\text { there is a direct link between improved } \\
\text { financial knowledge, enhanced personal } \\
\text { financial wellness and employee } \\
\text { productivity. An Employee cannot perform } \\
\text { better if his / her mind is preoccupied by } \\
\text { the financial distress he/she is suffering. }\end{array}$ & 90 & 4 & 6 & 86 \\
\hline $\begin{array}{l}\text { Q18. Exposure to financial education is a } \\
\text { necessary, but not a sufficient condition for } \\
\text { an educated middle class person to go for } \\
\text { financial planning. }\end{array}$ & 64 & 23 & 13 & 41 \\
\hline $\begin{array}{l}\text { Q19. A "Do it Yourself Financial } \\
\text { Planning" kit incorporating financial } \\
\text { planning best practices should be made } \\
\text { available to educated middle class persons, } \\
\text { who have formal financial education but do } \\
\text { not want to avail the services of financial } \\
\text { planning advisors. }\end{array}$ & 75 & 13 & 12 & 62 \\
\hline $\begin{array}{l}\text { Q20. Financial Planning education } \\
\text { providers, who are approved by FPSB - } \\
\text { India, are doing a commendable job as far } \\
\text { as steadily increasing the number of CFP } \\
\text { pass outs in India is concerned. }\end{array}$ & 66 & 6 & 28 & 60 \\
\hline
\end{tabular}

(Table 4)

Kids

\section{Major Findings of the Survey:}

(i) Imparting real life financial skills to school students is critical to their holistic development. Establishing sound financial habits at a young age will prepare them for financial success in future. If children are not equipped with the right skills, they will have a miserable time, learning financial lessons the hard way and making some horrendous mistakes.

\section{School Children}

(ii) It is worthwhile to provide relevant financial education to school students free of cost through school, print media and electronic media, conduct a certification test at national level and provide appropriate incentives for clearing the test.

\section{College / University Students}

(iii) Personal finance should be compulsorily taught to college / university students. Those who are majoring in finance must study personal finance before they study corporate finance. Colleges / Universities may consider running regular financial counselling clinics with the help of reputed financial advisors to advise students on financial matters, especially on borrowings, spending on credit cards, saving and investing opportunities.

\section{Women}

(iv) Women face tremendous challenges as they move through life's transitions, from childhood to adult, from college to career, from single to married, to widowhood or divorce, and into the retirement years. And women are concerned about the financial well-being of their families as well as themselves, making sure that those they love are sheltered within their own financial success. So women should be financially empowered for their success in life. Women play multiple roles as mother, wife, sister, daughter, daughter- 
in-law etc, during their life time in the family. It would be prudent to involve women in the financial decision making process in the family. Once they understand finance and get used to taking financial decisions, they can easily teach, if not anyone else, their own children.

\section{Teachers}

(v) Teachers should endeavour to improve financial capability among young students by using financial tools, resources and activities to make the classroom fun and engaging. Providing appropriate training to teachers engaged in delivering financial education to students may help achieving this goal.

\section{Parents}

(vi) A child starts learning invaluable lessons, from the time he takes birth, from his parents. Parents, therefore, must learn the basics of saving, investing, and financial planning for themselves and their loved ones' future. Parents should discuss finance and their finance related decisions with their children so as to make them financially savvy.

\section{Defence Personnel}

(vii) Defence personnel face unique financial challenges. They must learn how to navigate their financial futures post retirement from defence services. Many of them also take retirement at middle age, after completion of a minimum required number of years in service. Finance education for defence personnel is therefore extremely important and may be provided while they are in service and subsequently by the rehabilitation wing to the retirees.

\section{Retirees / Senior Citizens}

(viii) Retirees must be given adequate financial education as regards to the steps they and their families can take to achieve financial security and financial independence in life in the post retirement period. NGOs, Developmental Agencies and Insurance Companies who offer retirement planning advice may take the lead to address the personal finance education needs of retirees and senior citizens. Young and educated children of the retirees and senior citizens may also help educating their old parents on finance matters.

\section{Employees}

(ix) Financial education within the workplace has become a necessity because there is a direct link between improved financial knowledge, enhanced personal financial wellness and employee productivity. An Employee cannot perform better if his / her mind is preoccupied by the financial distress he/she is suffering. Employers who offer personal finance education to employees under their employee benefit scheme convey that they are concerned with their long term welfare. However, employers typically offer only narrowly focused financial education about retirement. They should offer comprehensive personal finance employee education, because the cost is low and benefits are high.

Coded Score, less than 70 in case of Q4 (63), Q18 (41), Q19 (62) and Q20 (60) was considered low and deserved appropriate explanation. There is a growing feeling in India that, "There is no free meal", i.e. nothing should be made available free, as, if it is free, its real value will not be understood and thus it will not find a desirable use. This thinking might have prompted the respondents to give a low score to Q4. Q18 might have raised a big question mark in the minds of the respondents. Many who have high level of finance education even do not go for monthly budgeting, the very basic of financial planning. Only a very few might have adequate saving for retirement and counted few might have written a will. Thus it is very difficult to answer the question whether education alone can prompt a positive reaction. This confusion could have lead to a low coded score for Q18. Since in India, we don't have adequate awareness and understanding about financial planning, especially among educationists, who do not have training in finance, the concept of having a "Do it yourself financial planning kit" might not have been properly understood. Hence, the low score for Q19. It has been observed that practitioners and experts have not yet reposed confidence in the working and performance of FPSB-India and the approved educational providers. Since FPSB-India is hardly 6 years old, it is but natural that it has not yet gained popularity among practitioners, as such, so far it has not been able to live up to their high expectations. Low score for Q20 may be because of this reason.

\section{Role of Government and Financial Institutions in spreading financial literacy and disseminating financial education in India}

OECD in 2005 had formulated certain principles and good practices for financial education and awareness. The aim of these recommendations was to help governments and policy makers to design and implement effective financial education programmes. These principles contained suggestions on: (1) How governments can increase public awareness of financial issues? (2) How financial institutions can provide objective information on financial products? (3) The role of employers in the provision of financial information 
and (4) What the providers of retirement savings products need to consider in determining the content and delivery of financial education programmes? Further in 2006, the OECD developed and adopted financial education guidelines and good practices in the pensions and insurance sectors. In light of the recent developments in the mortgage and credit markets, the OECD is analysing policy issues related to financial education in the area of credit, and this will likely result in the development of further guidelines for that sector. Another component of the OECD programme relates to promoting international cooperation on financial education. Indian Government can take the clue from its US counterpart and follow OECD's guidelines / recommendations to promote financial literacy and disseminate financial education among Indian masses.

\section{What Indian Government should do?}

US Endeavours
Financial Literacy and Education Commission has formulated
a National Strategy for Financial Literacy, 2011 for
Promoting Financial Success in the United States. National
Strategy Working Group (NSWG) has identified four goals for
National Strategy, 2011:
1. Increase awareness of and access to effective financial
education;
2. Determine and integrate core financial competencies;
3. Improve financial education infrastructure; and
4. Identify, enhance, and share effective practices.
The purpose of the National Strategy 2011 is to create an
overarching strategic framework that all organizations
involved with personal finance education, research, practice,
and policy will find useful to help guide their work over the
next several years. The aim is for stakeholders across the
country-within the federal government and beyond-to
develop, implement and evaluate specific objectives that
support and advance the elements of the national strategy to
work together to achieve the shared vision of financial well-
being for all people in the United States.
MyMoney.gov is the U.S. government's website dedicated to
teaching all Americans the basics about financial education.
This site organizes financial education help from over 20
different Federal web sites in one place. Content is organized
by where you are in life ("Life Events"), who you are ("My
Resources"), and by specific hands-on tools ("Tools"). Popular
Topics are also highlighted. This site provides summaries of
resources available at other official government sites.
Popular topics on which resources are available on this site
include (i) Spending Plan (ii) Managing Debt and Credit (iii)
Dealing with Mortgages (iv) Planning for Retirement (v)
Getting a Loan (vi) Getting Insured (vii) Knowing Your
Consumer Rights and (viii) Scams/ Fraud.
http://www.mymoney.gov/myresources.html
Meing

MyMoney.Gov Provides financial information from trusted resources for (i) Youth (ii) Teachers (iii) Parents and Caregivers (iv) Women (v) Employers (vi) Military Personnel (vii) Retirees (viii) Researchers (ix) Financial Education Providers. Helpful financial information are also available based on life events like (i) Birth/ Adoption of a Child (ii) Going to College (iii) Marriage / Divorce (iv) Starting / Losing a Job (v) Starting / Buying a Business (vi) Buying a Home (vii) Planning for Retirement / Retiring (viii) Death of a Family Member (ix) Natural Disaster and Unexpected Events. FINRA Investor Education Foundation

(http://www.finrafoundation.org/resources/education/learning/) has developed a host of learning materials for financial education, which include, (i) The Gen $\boldsymbol{i}$ Revolution is a competitive online game developed by the Council for Economic Education to teach personal finance skills to middle and high school students (ii)Are You Financially Fit? A brochure and a workbook (iii)Your Mind and Your Money, feature series exploring behavioral finance and its implications

\author{
Recommendation for India \\ India needs to formulate a National Strategy for \\ financial Literacy on similar lines
}

Government of India should take a similar initiative immediately.

Indian Government needs to develop a similar trusted and reliable repository of resources for all target groups and stakeholders. 


\section{(iv)The Investor's Guide to Securities Industry Disputes: How to Prevent and Resolve Disputes with Your Broker, a brochure (v)Get Your Finances Ready for Retirement (vi)TV411 Save Smart, multimedia toolkit (vii)Get Rich Slow, women's retirement game (viii)Financial Literacy Training for High School Students etc.}

U.S. Securities and Exchange Commission (SEC) has created a site for investor education http://investor.gov/ which deals with topics like (i) Introduction to Markets (ii) Investing Basics (iii) Researching and Managing Investments (iv) Employment to Retirement (v) Life Events etc.

There are several institutions in USA, both in the Government and Private sectors which are providing excellent and reliable financial education to specific target groups like (i) Women (ii) School Kids (iii) College and University Students (iv) Military Personnel (vi) Retirees / Senior Citizens and (vii) Parents \& Teachers
However, RBI has to do much more to be as effective as FINRA

NISM promoted as an educational initiative of SEBI has created a website http://investorfirst.in/ on similar lines to offer unbiased investor education.

(Table 5)

India does not have such facilities. Government of India has to take the lead in this respect and encourage financial institutions, private bodies, NGOs, Voluntary Organizations and others to assist it in its endeavour. FPSB-India and the education providers should also be encouraged to supplement these efforts.

\section{Epilogue}

Indian government and regulatory bodies must appreciate the vital need of finance education for the Indian society and start doing their bit to strengthen the financial capability of Indian citizens. Brigham Young has rightly said, "Education is the power to think clearly, the power to act well in the worlds work, and the power to appreciate life". In the words of Nelson Mandela, "Education is the most powerful weapon which you can use to change the world."

\section{References:}

[1] Financial Industry Regulatory Authority (FINRA) Investor Education Foundation (2010), Financial capability in the United States, Military survey - Executive Summary, October 2010

[2] Cox, L.K. (2011), Growing List of Financial Problems Plagues Military Members, Wallet Pop, $24^{\text {th }}$ Feb,2011 (10 AM)

[3] Garman, E.T.(1998), The Business Case for Financial Education, Personal Finances and Worker Productivity, vol.2, No.1, June, 1998.

[4] Garman, E.T., Leech, I.E, Grable, J.E.(1996), the Negative Impact of employee poor personal financial behaviours on Employers, Financial Counseling and Planning, Vol.7, 1996.

[5] Hira, T. K. \& Loibl, C. (2005). Understanding the impact of employer-provided financial education on workplace satisfaction. Journal of Consumer Affairs, 39(1), 173-194.

[6] Kim, J. (2000). The effects of workplace financial education on personal finances and work outcomes. Doctoral Dissertation, Blacksburg: Virginia Polytechnic Institute and State University.

[7] Kim, J. (2007). Workplace financial education program: Does it have an impact on employees' personal finances? Journal of Family and Consumer Science, 99(1), 43-47.

[8] Kratzer, C.Y., Brunson, B. H., Garman, E.T., Kim, J and Joo, S.(1998), Financial Education in the workplace: Result of a research study, Journal of Compensation and benefits, Vol.14, No.3, pp.24-27

[9] Mishra L (2011), A study of Financial Planning Awareness, Education and Advisory from an Indian perspective with special reference to the Educated Middle Class, Unpublished PhD Thesis

[10] OECD (2005), Recommendation on Principles and Good Practices for Financial Education and Awareness, Directorate of Financial and Enterprise Affairs, July 2005

[11] OECD (2006), Improving Financial Literacy: Analysis of Issues and Policies.

\section{Websites:}

[12] http://www.saveandinvest.org/Military/manageMoney/ Free unbiased financial information for military families and old investors.

[13] http://www.personalfinancefoundation.org/ To promote and facilitate financial education in the work place.

[14] http://www.financialfinesse.com/ Unbiased financial education programme to help employees.

[15] http://www.finra.org/microsites/moneymobility/Money_and_Mobility.pdf

[16] Money and Mobility: an E-book for military personnel and families (2009 revised edition) - Manage Your Money with Confidence

[17] http://www.investorfirst.in/resources/ It is an effort of NISM (an institution established by SEBI) to offer unbiased investor education.

[18] http://www.nism.ac.in/ NISM is a public trust established as an educational initiative by SEBI

[19] http://www.rbi.org.in/financialeducation/ RBI's Financial Education Initiative

[20] http://www.wife.org/ The Women's Institute for Financial Education (WIFE.org) is the oldest non-profit organization dedicated to providing financial education to women in their quest for financial independence.

[21] http://www.financialeducationforwomen.com/ Educate Senior and Pre-Senior Women about insurance, investment, wills and trusts etc.

[22] http://www.ifuw.org/index.shtml International Federation of University Women empowering women and girls through lifelong education

[23] http://www.financiallit.org/xpages/InstituteforFinancialLiteracyLaunchesFinancialEducationProgramDesignedforSeniorCitizen.a $\underline{\text { spx }}$ Institute of Financial Literacy’s programme for senior citizen 
[24] (http://www.dfi.wa.gov/consumers/education/seniors.htm) Provides important financial tips for senior citizens.

[25] http://www.financial-education-icfe.org/children_and_money/index.asp ICFE kids section offers money tips for kids

[26] http://clearinghouse.jumpstart.org/resource/368/ Financial Education for Young Persons

[27] http://www.financial-education.org/ OECD's Financial Education Site. OECD has 75 member countries including India.

[28] http://www.themint.org/ A website for financial education of kids, parents and teachers.

[29] http://www.thefinancialfairytales.com/ Financial learning for kids

[30] http://www.financial-education-icfe.org/children_and_money/ Financial education for kids and youth

[31] http://www.rbi.org.in/financialeducation/home.aspx RBI's Project Financial Literacy. 